\title{
Leading as Jesus Led: Christ Models of Leadership
}

\author{
Gabriel Kofi Boahen Nsiah \\ Faculty of Arts and Social Sciences, Valley View University, Accra, Ghana \\ Email: gabrielnsiah@gmail.com
}

Received October $19^{\text {th }}$, 2013; revised November 19 $9^{\text {th }}$, 2013; accepted November $25^{\text {th }}, 2013$

\begin{abstract}
Copyright (C) 2013 Gabriel Kofi Boahen Nsiah. This is an open access article distributed under the Creative Commons Attribution License, which permits unrestricted use, distribution, and reproduction in any medium, provided the original work is properly cited.
\end{abstract}

\begin{abstract}
Good leadership is a challenge in most institutions and organizations in our world. This problem emanates from having the right people to lead in such institutions and organizations. People have assumed leadership responsibilities by virtue of the positions they occupy but they do not have the requisite leadership training for that position. Others also have looked up to certain individuals who have their own challenges. The problem of leadership in our world therefore calls for studies in finding solutions to the problems. In view of this, Jesus Christ, the greatest leader ever lived, is brought into perspective. Christ leadership models will inform all leaders as to what it takes to be a true leader. If these models are adopted, it will help improve leadership skills in all institutions and organizations.
\end{abstract}

Keywords: Leadership; Leader; Servant Leadership; Model

\section{Introduction}

Everyone demonstrates a certain level of leadership at some point in life; formal or informal. In other words, we are all leaders in one way or the other. In the home, parents are the leaders. The children also exercise leadership roles and responsibilities as being assigned by their parents or by themselves. This could be termed informal or unofficial leadership. Official leadership is leadership exercised either through appointment, nomination or election by an established institution.

As much as leadership is exercised at every level of society, but not every leader is versatile. In other words, there are good leaders and bad leaders. While some receive training to assume leadership responsibilities, others are leaders by virtue of the position they occupy.

Leaders are expected to exhibit certain qualities. In view of this, leaders have looked up to different individuals as their role models. The greatest role model ever lived on our planet is Jesus Christ. Jesus is a perfect example of all that we need to know when it comes to leadership. If leaders would model the greatest leader who ever lived, we would have a perfect society. This article discusses the leadership models exhibited by Christ when on earth.

\section{Servant Leadership}

Servant leadership refers to the philosophy of leadership that puts serving others as the topmost priority. It calls for a holistic approach to work, a sense of community and the sharing of power in decision making (Questia, 2013). According to the New York Times, servant leadership deals with the reality of power in everyday life-its legitimacy, the ethical restraints upon it and the beneficial results that can be attained through the appropriate use of power (October 2, 1990).

In Mathew 20: 24-28, Jesus spoke about servant leadership:

When the ten heard about this, they were indignant with the two brothers. Jesus called them together and said, "You know that the rulers of the Gentiles lord it over them, and their high officials exercise authority over them. Not so with you. Instead, whoever wants to become great among you must be your servant, and whoever wants to be first must be your slave-just as the Son of Man did not come to be served, but to serve, and to give his life as a ransom for many."

The apostle Peter in I Peter 5: 1-4 also spoke clearly about servant leadership:

To the elders among you, I appeal as a fellow elder and a witness of Christ's sufferings who also will share in the glory to be revealed: Be shepherds of God's flock that is under your care, watching over them-not because you must, but because you are willing, as God wants you to be; not pursuing dishonest gain, but eager to serve; not lording it over those entrusted to you, but being examples to the flock. And when the Chief Shepherd appears, you will receive the crown of glory that will never fade away.

Robert K. Greenleaf, founder of the modern Servant Leadership movement and the Greenleaf Center for Servant Leadership, explained who a servant leader is and how it works. According to Greenleaf (1970).

The servant-leader is servant first. It begins with the natural feeling that one wants to serve. Then conscious choice brings one to aspire to lead. The best test is: do those served grow as persons: do they, while being served, become healthier, wiser, more independent, more autonomous, more likely themselves to become servants? What is the effect on the least privileged in society; will they benefit, or, at least, not be further deprived? (p. 27)

The Fortune Magazine also explained that:

Servant-leadership works like the consensus-building that the Japanese are famous for. Yes, it takes a while on the front end; everyone's view is solicited, though everyone also understands that his (or her) view may not ultimately prevail. How- 
ever, once the consensus is forged, watch out: With everyone on board, your so-called implementation proceeds (May 4, 1992, as cited in Greenleaf, 1998: p. 13).

In John 13: 3-5, Jesus demonstrated a servant leadership role by washing the feet of his disciples so they could partake of the last supper:

Jesus knew that the Father had put all things under his power, and that he had come from God and was returning to God; so he got up from the meal, took off his outer clothing, and wrapped a towel around his waist. After that, he poured water into a basin and began to wash his disciples' feet, drying them with the towel that was wrapped around him.

The above demonstration is a perfect leadership model every leader or prospective leader must learn and adapt to. Christ was so humble to the extent of taking off His robe, picking up a towel and bowing down to wash the feet of his followers. According to Finzel (2000), "servant leadership requires us to sit and weep with those who weep within our organizations. It requires getting down and dirty when hard work has to be done." In other words, servant leadership requires us to do the miniature jobs such as trimming and watering the plants, sweeping and mobbing the floor, picking up or throwing away trash, arranging the desk and chairs for a meeting, attending to the needs of our workers, etc. when the need arise.

Christ's servant leadership model demonstrates that leaders are called to serve but not to be served. Humility does not take away respect. It portrays a Christ-like nature of a person as a leader. I believe leaders who exhibit this trait will build trust and respect with their employees. Servant leaders would inspire their followers to work selflessly because of the respect shown them by their leaders. Other leadership qualities exhibited by Jesus are discussed below:

\section{Vision}

Another leadership model exhibited by Christ is vision. Christ foresees the end from the beginning. In Matthew chapter 9:2, a paralytic was brought to Christ for healing. According to the passage, when Jesus saw their faith, he knew what they wanted and said to the paralytic, "Son, be of good cheer." Jesus had not had any encounter with the man but was able to envision the cause of the paralysis.

This is one of the most important qualities or skills a leader must possess. Without vision, progress and development will be obstructed. A leader should be able to foresee the end from the beginning, must have foresight to know what is coming up next. Vision brings about innovation, progress and development. A leader who does not possess this quality could be compared to a ship that moves without particular direction. Not only should a leader possess visionary skills or quality, a leader's vision should be well stated and comprehensible to enable the organization put the vision into reality.

\section{Inter-Personal Intelligence}

Inter-personal intelligence may be defined as the ability to recognize or differentiate between people by face and voice; to react appropriately to their needs, to understand their motives, feelings and moods and to appreciate such perspectives with sensitivity and empathy (Inspirational Breakthrough, 20032005). In Matthew 9:4, Jesus exhibited inter-personal intelligence. After telling the paralytic his sins are forgiven, He read the thoughts of some of the Scribes, when they said within themselves that He (Jesus) had blasphemed for saying that the paralytic's sins are forgiven. Inter-personal intelligence is a vital leadership skill. It enables a leader to perceive and understand the emotions of employees; their moods, desires and motivations. This would be very healthy for an organization. Understanding the feelings of workers will enable a leader meet their needs. When workers get satisfaction or have their needs met, production will be affected positively.

\section{Non Segregationist}

Another leadership quality exhibited by Christ is His impartial love for all. In John 4: 4-42, Jesus crosses both social and religious barriers. In the story of the Samaritan woman, Jesus did not only converse with a Samaritan, but a Samaritan who was a woman. Jewish culture in those days frowned on conversations between male and female. Besides, the Jews and Samaritans did not get along, but Jesus crossed those barriers. Our society today and leaders in particular, need to cross these barriers as well. Some women suffer to gain employment in many places in the world because of their gender. Some organizations or individuals would not employ a woman because a woman may need maternity leave and other breaks when employed. Others also suffer unemployment because of their race, sex or tribe. Jesus models the style for all leaders. Leaders must avoid all forms of discriminations and provide equal opportunity for everyone. Also, in John 11, Jesus crossed the social barrier by having a conversation with a woman called Martha of Bethany.

\section{Teaching}

In Matthew 6: 5-14, Jesus model as a teacher. He taught his disciples how to pray. Leaders must possess teaching skills. Leaders will have to teach their employees certain things they need to know about the organization. Even though experts could be invited to speak on certain issues, a leader must demonstrate his or her competency to teach employees once a while.

\section{Resource Provider}

Another model of Christ leadership is depicted in John 2:1-11. Jesus modeled care: He was the resource provider for a wedding. According to the story, the wedding banquet run out of wine and Jesus provided some by turning water into wine. Leaders have the responsibility to provide resources for their organizations or institutions. Without the needed resources, organizations cannot function. Leaders must ensure that both human and material resources are made available to the organization to enhance production. Had it not been the presence of Jesus at the wedding, the banquet would have been brought to a premature end due to inadequate supply of resources, in this situation, wine. In the thick of the emergency situation, Christ demonstrated his leadership skills by providing wine to serve the guests.

Christ also demonstrated to leaders that their skills are not limited to being used to serve the organizations they serve; they must be a blessing to all people at all times and in any place they find themselves. Christ was an invited guest at the wedding, but He stepped in when it mattered most. A true leader is one who skillfully handles emergency situations by providing the needed support for the organization or community as a 
whole.

\section{Compassion}

Jesus also exhibited a unique character in John 5: 5, 6: 5, 9, 11, and Matthew 14: 14. In John 5: 5-9, Christ had compassion on a man who had lain by a pool side for thirty-eight years. The man was made whole when Christ asked him to pickup his bed and walk. In John 6: 5, Christ had compassion on a multitude that came to listen to him. He fed them until they were full and there were left-overs. In John 9, Christ showed compassion toward a blind man. The man had been blind since birth but when he met Christ, he received his sight. Also in John 11, Lazarus was resurrected from the grave when he received compassion from Christ.

Leaders need compassion in other to treat their workers humanely. Jesus performed those miracles so we will also learn to treat others humanely and learn to give others a second chance. Leaders need to let their workers or followers feel good about themselves. This will heighten motivation and boost production.

\section{Delegation with Authority}

In Matthew 10, Christ delegated responsibility to his disciples. He sent them to go out and preach the gospel, baptizing anyone who accepted the Lord as his personal Savior. Jesus did not only delegate responsibility to the disciples; He also gave them authority over evil spirits and power to heal disease. I am wondering how many leaders feel comfortable delegating responsibility to their workers, and will also give them authority to act on their behalf. Some leaders feel that their positions are threatened if they should allow delegation of responsibilities to other people.

Delegation is vital in leadership and administration. Most leaders are burning out because they have not learned to delegate responsibilities. Delegation would reduce the workload on a leader, therefore a good leader must learn to entrust responsibilities to others. A good leader is one who has somebody to assume his responsibilities when absent. In the absence of a leader, if there is no one to assume your responsibilities and perform the functions well, then that leader is a failure.

To avoid burnout, leaders must learn to delegate responsibilities to other people. This is healthy, for it would prolong their life and enhance production. As they say two heads are better than one. In other words, no one has monopoly on knowledge. Through delegation, others would receive training to assume leadership responsibilities in the future. Christ delegated and so must we.

\section{Prayerful}

Another leadership trait Jesus exhibited is his prayerfulness and coping skills, especially in difficult situations. As a man, he was tempted as we are: beaten, spat upon, mocked, and yet was still without sin. I believe Christ was successful in enduring the challenges through prayer. Before he was delivered up to the Jews, he was praying in the garden of Gethsemane (John 17). Prayer gives us the strength to endure challenging times. A leader, if religious must learn to pray. Prayer clears the mind and improves concentration. Through prayer, leaders can have wisdom. As the scriptures teaches in Proverbs 9:10, "the fear of the Lord is the beginning of wisdom.” If leaders would learn to depend upon the source of their power, there is nothing they would lack, no matter how the situation may be. Through prayer, leaders can relate well to their workers and build a positive working environment.

\section{Sense of Purpose}

Above all, having a sense of purpose enabled Christ to endure all the trials and temptations he went through. His sense of purpose was greater than his feelings. A leader must eliminate self and work for the benefit of others. Matthew 6:3 reads "seek first the kingdom of heaven and its righteousness, and all other things shall be added unto you.” If leaders would learn to seek God first, they will find wisdom to prosper their businesses or organizations. Leaders must learn to commit themselves to the people they are called to serve. By committing oneself to accomplish the purpose of the organization, the Lord will make all the necessary tools available for success.

\section{Conclusion}

Everyone is a leader but not all leaders are good. However, we must all aspire to be good leaders and to be a good leader, one need to undergo training or have a mentor. There are good human leaders but the greatest and the perfect role model is Jesus Christ, the Creator of the Universe. His leadership quailties are incomparable to those of any human leader. By making Christ our role model, we would lead aright and be able to change society for the better.

\section{REFERENCES}

Finzel, H. (2000). The top ten mistakes leaders make. Eastbourne: Kingsway Communications.

Greenleaf, R. K. (1998). The power of servant leadership. San Francisco, CA: Berrett-Koehler Publishers, Inc.

Greenleaf, R. K. (1970). The servant as leader. Robert K. Greenleaf Publishing Center.

Inspirational Breakthrough (2003-2005).

http://www.inspiring-breakthrough.co.uk/learning-styles/interpersona l-learning.htm

Questia (2013). Servant leadership.

http://www.questia.com/library/psychology/groups-and-organization s/leadership/servant-leadership

The New York Times (October 1990).

http://articles.chicagotribune.com/1990-10-07/news/9003230336_1_f ord-foundation-center-for-applied-ethics-at-t 